\title{
Medievalista
}

\section{Evidências de Patrocínio em Bestiários Medievais}

Evidences of Patronage in Medieval Bestiaries

\section{Tiago de Oliveira Veloso Silva}

\section{(2) OpenEdition}

Journals

Edição electrónica

URL: https://journals.openedition.org/medievalista/3877

DOI: 10.4000/medievalista.3877

ISSN: 1646-740X

\section{Editora}

Instituto de Estudos Medievais - FCSH-UNL

\section{Edição impressa}

Paginação: 117-148

\section{Refêrencia eletrónica}

Tiago de Oliveira Veloso Silva, «Evidências de Patrocínio em Bestiários Medievais», Medievalista [Online], 29 | 2021, posto online no dia 01 janeiro 2021, consultado o 12 junho 2021. URL: http:// journals.openedition.org/medievalista/3877 ; DOI: https://doi.org/10.4000/medievalista.3877

Este documento foi criado de forma automática no dia 12 junho 2021.

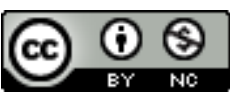

Mediavalista está licenciado com uma Licença Creative Commons - Atribuição-NãoComercial 4.0 Internacional. 


\title{
Evidências de Patrocínio em Bestiários Medievais
}

\author{
Evidences of Patronage in Medieval Bestiaries
}

Tiago de Oliveira Veloso Silva

\section{NOTA DO EDITOR}

Data recepção do artigo / Received for publication: 13 de Novembro de 2019

Data aceitação do artigo / Accepted in revised form: 10 de Julho de 2020

1 Este artigo propõe analisar dois manuscritos, o bestiário de Aberdeen Ms. 24 e o bestiário Bodley Ashmole Ms. 1511. 0 estudo destes dois manuscritos procura destacar o que podemos chamar de evidências visuais de patrocínio, ou seja, aspectos específicos destes dois manuscritos que podem identificá-los como resultantes de um processo de patrocínio medieval. Será feita a análise imagética da iluminura da Pêga (Pica) em ambos os bestiários, e contrastadas com iluminuras presentes em outros seis bestiários. Procura-se mostrar que o elemento adicional do caçador não existe em outras iluminuras, e por isso sugere-se que sua existência é resultado de uma motivação exterior. Dispondo-nos de trabalhos prévios e hipóteses já tratadas por alguns pesquisadores, este artigo reflete sobre a condição material de ambos bestiários, seu contexto de produção e contexto histórico para sugerir que o Ms. 24 e o Ms. 1511, ou seu modelo, foram resultados de uma encomenda feita por um indivíduo participante da elite medieval e que este patrono possivelmente encomendou ao menos um dos manuscritos para presentear alguém ou alguma instituição.

O estudo da materialidade de manuscritos medievais é um campo que pode ser aliado às outras formas de análise de manuscritos como a linguística, artística ou simbólica, assim nos auxiliando a responder perguntas importantes sobre a fonte e toda sua relação com aspectos culturais, sociais e econômicos do medievo. Parte da cadeia que resulta na criação de um manuscrito é passível de observação em seus fólios, iluminuras e decorações, permitindo-nos investigar mais a fundo a inserção do manuscrito na 
cultura da época. Com um processo complexo, que vai da raspagem do couro do animal até finalização da ornamentação, os manuscritos medievais possuíam um processo de elaboração lento, caro, e de público restrito, dado o baixo índice de pessoas alfabetizadas, se limitando no geral à monastérios e catedrais, ou seja, os mesmos que os produziam, a Igreja.

3 Através do estudo da materialidade dos manuscritos, percebe-se condições sociais, econômicas e culturais que influenciaram sua produção, isto é, conhecer a produção dos manuscritos é conhecer melhor a Idade Média. A observação da materialidade nos possibilita, entre outros, analisar o patrocinador do manuscrito; este ângulo de análise nos permite identificar questões de consumo literário, demonstrações de poder, contextos religiosos e filosóficos relevantes para a época, e diferentes outros pontos que nos permitem entender melhor a tessitura sócio-cultural da época.

4 A grande consumidora de manuscritos durante o medievo era a Igreja, que comprava e patrocinava a produção dos mesmos para a disseminação do estudo religioso com cópias de manuscritos gregos ${ }^{1}$ e latinos, visando o desenvolvimento e amadurecimento intelectual e filosófico religioso. Além das elites eclesiásticas, a participação das elites seculares no consumo de literatura também era presente, especialmente durante o medievo tardio. A grande participação da elite secular estava no patrocínio de mosteiros, e, consequentemente, de sua grande produção artística ${ }^{2}$, portanto, a produção de obras artísticas e literárias cujo fim era a exaltação de tais patronos não era rara. Em manuscritos, a suntuosidade, ou seja, utilização de ouro, pedras preciosas na capa, e pigmentos raros indica que o patrocinador ou patrocinadora do manuscrito faz parte da elite social que seria capaz de pagar por tal luxuosidade. Pode-se supor também que o uso de manuscritos luxuosos também se diferenciava bastante dos mais simples, não só em usuários/consumidores do produto, mas possivelmente também na forma de uso. Quando tratando de bestiários, vemos que existem um número reduzido de cópias de luxo sobreviventes, considerando apenas a Segunda Família de bestiários, a com maior número de manuscritos de luxo, podemos observar que existem 11 manuscritos de luxo de um total de 49 manuscritos, 22,5\% são de luxo. Caso o número de manuscritos seja dividido em datas, 7 dos 11 manuscritos de luxo foram produzidos entre 1180 e $1250(63,5 \%)^{3}$. A identificação de patrocinadores de manuscritos é, muitas vezes, difícil e raramente conclusiva, dependendo de marcadores de identificação que auxiliem na distinção do patrocinador; a mesma lógica segue quando analisados bestiários. Dentre os 49 manuscritos da Segunda Família, é possível identificar em alguns aspectos claros de patrocínio, como símbolos e marcas heráldicas em iluminuras, como é o caso do Bodleian Ms. Ashmole 764, explorado por Ron Baxter ${ }^{4}$.

Bestiários são um tipo de manuscrito medieval descendente do Physiologus ${ }^{5}$, com influências de tratados de São Ambrósio, Isidoro de Sevilha e outras autoridades medievais, onde diversos animais são descritos e moralizados. Nos bestiários, é possível observar a amplitude do pensamento analógico e metafórico medieval, onde vemos que os animais, assim como a totalidade do mundo natural incluindo plantas e rochas, eram utilizados como analogias morais e espirituais. Resultado de uma mistura entre descrição e moralização cristã típica do medievo, Michel Pastoureau diz que: "Se eles [bestiários] se debruçam sobre as "propriedades" dos animais e sobre as maravilhas de suas "naturezas", não é tanto para se dissertar sobre a anatomia, a etologia ou a biologia dos animais quanto para celebrar a Criação e o Criador, para ensinar as verdades da fé, para convidar os fiéis a se converterem"6. 
6 Logo, uma vez que, para os cristãos, Deus foi o criador de tudo, os mesmos buscavam nas leis da natureza obras de Deus, mensagens divinas significativas acerca da moral e comportamento cristão, ou seja, viam o “(...) universo sendo o símbolo das realidades espirituais" . A partir da observação do universo, logo, da natureza, os animais eram vistos como portadores de uma lição divina que deveria ser decifrada e compreendida pelo homem medieval em busca da harmonia que reflete a perfeição de Deus.

7 Apesar de carregados de significado, nem todos os animais presentes em bestiários possuem em seu texto ou iluminura uma referência moral clara e direta, como pode-se observar quando analisa-se algumas aves ou serpentes. Nestas, a parte descritiva do animal toma conta do texto, e, normalmente, as iluminuras que acompanham o tratado destes animais são menores e ocupam menos espaço, logo, possivelmente possuem uma importância menor dentro do conjunto do bestiário. Uma vez que este é um manuscrito de alegorias moralizantes, compreende-se que aqueles que não possuem tal propósito moral possam ter uma dimensão textual e imagética, assim como relevância moral, menor que as que possuem um cerne moralizante. No entanto, tratados de animais não moralizados podem ter sido utilizados também como um exercício de estímulo para a criação de novas moralizações ${ }^{8}$, como nos sugere Clark.

8 As iluminuras maiores e menores, retornando a Pastoureau, refletem um sistema de valores hierárquicos intrínsecos na sociedade medieval, em uma clara disposição de hierarquia simbólica, moral e animal ${ }^{9}$. Isso nos remete a uma importante relação presente nos bestiários medievais entre o texto e a iluminura, onde a imagem, grande parte das vezes, reflete o conteúdo presente no texto. A sincronia entre texto e imagem, que pode refletir completa ou parcialmente o texto, pode ser observada em todos os bestiários, ou seja, é uma constante neste tipo de manuscrito que nos fornece um olhar sobre a tradição da correspondência entre iluminura e texto nos bestiários. Essa tradição de correlação ao mesmo tempo que mantêm uma unidade coerente entre ambos elementos do manuscrito, nos permite observar seus desviantes e apontá-los como tal.

9 A relação imagem-texto presente no bestiário faz parte de uma tradição muito mais ampla e difundida no medievo, onde as figuras ou imagens poderiam ser utilizadas para explicar e transferir o conhecimento religioso. Duby, tratando neste caso sobre a arquitetura, diz que as figuras das fachadas de edificações religiosas eram colocadas "à vista dos que não sabiam ler, como uma transposição visual do seu saber"10. Partindo do pressuposto de difusão do conhecimento, logo, um motivo pedagógico para sua existência, o bestiário e suas iluminuras também são reflexos deste método de didática medieval que combina a instrução com a metáfora simbólica. Jean-Claude Schmitt defende que a relação entre texto e imagem remonta ao Papa Gregório Magno, onde o mesmo defende que a imagem é o texto para aqueles que são iletrados ${ }^{11}$. No entanto, Schmitt acrescenta que a imagem é definida por referências à escrita, e pensada inteiramente a partir da leitura de um texto, o que aplica-se também a bestiários. Ausente de um texto que a explica, a imagem referente normalmente se torna incompreensível, por exemplo, o tratado do abutre no bestiário de Aberdeen Ms. $24^{12}$ trata em seu texto, entre outras coisas, da descrição da reprodução da mesma. A reprodução do abutre é descrita como um caso específico onde as aves não precisam engajar na cópula, ou seja, a ave tem seus filhotes mas se mantém pura abstêmia de sexo. Tal característica é utilizada no texto como uma crítica àqueles que não acreditam que Maria, a mãe de Jesus, possa ter tido seu filho sem ter se corrompido à carnalidade 
do ato sexual, utilizando como argumento que tal possibilidade existe na natureza, criada por Deus, e logo, a castidade de Maria é inquestionável. Esta é apenas uma das características moralizadas do abutre, sendo a outra ambígua, uma metáfora tanto para Cristo quanto para pecadores, mas sua iluminura representa apenas dois abutres cruzados, um para cada lado, dentro de um círculo e com suas cabeças voltadas um para o outro e seus bicos quase se tocando. Tal iluminura pode ser compreendida como uma representação da relação entre dois abutres no não engajamento da cópula, podendo então sugerir que seus corpos virados de forma contrária um ao outro simulam a separação corporal e carnal, desnecessária para eles, mas suas cabeças estão voltadas uma para a outra num sinal de relação espiritual.

10 Entretanto, só podemos ter esta e outras percepções metafóricas da ave, ou outro animal, quando temos acesso ao conhecimento que neste caso é textual, e por isso a imagem está sujeita ao texto, que media o conhecimento transmitido nos tratados do bestiário. No entanto, existem diferentes casos que devem ser analisados de forma individual, como o caso de animais que não são moralizados. Há o caso de animais cujo valor simbólico é de amplo conhecimento no cristianismo, como é o caso da pomba ou dragão, que imediatamente sob observação de um cristão podem ser compreendidos como possuidores de um significado. No entanto, em quase todos os casos, a iluminura segue o direcionamento fornecido pelo texto, podendo ser compreendida ou não com a ausência do texto, mas a iluminura só será interpretada de forma completa e correta se há acesso ao texto, mesmo que a imagem faça alusão à conhecimentos prévios.

11 A imagem em manuscritos e sua compreensão então são sujeitas a uma explicação que é ditada pelo texto, possuindo assim uma condição indissociável. A imagem deve então deter-se ao que existe no texto, para que possa assim ser compreendida. No entanto, uma imagem, diferentemente de um texto, não consegue transmitir múltiplas cenas, ou seja, retornando ao caso do abutre, como o iluminador poderia em uma iluminura representar diversas passagens do tratado da ave? Não poderia, e, portanto, apenas algumas passagens são representadas. Pastoureau diz que os:

“(...) Iluminadores são conduzidos a fazer uma escolha, deixar de lado algumas páginas do texto, condensar outras; então, com o que eles escolheram, ou compartimentar a página (caso mais frequente), ou fundir em uma só cena os diferentes personagens, atributos, comportamentos, histórias e crenças sobre o animal. Fazendo isso, eles fabricam uma espécie de imagem sintética, fiel ao espírito do texto, mas que não são uma pura e simples ilustração da letra"13.

12 Diferentemente de Pastoureau, acredita-se aqui que a continuação e propagação de modelos e tradições iconográficas e imagéticas era mais determinante para uma reprodução imagética nos bestiários do que propriamente a escolha do iluminador ${ }^{14}$. Podemos observar que as iluminuras são uma imagem sintética, remetente ao texto, mas não uma simples ilustração da narrativa textual, elas constroem uma narrativa sintética própria edificada e suportada pela narrativa textual, portanto, dois elementos distintos, porém indissociáveis. A imagem, de certa forma limitada dentro dos moldes da possibilidade de representação, deve, portanto, sintetizar em sua narrativa uma das passagens sustentadas pelo texto.

Devemos retornar à função geral da imagem, neste caso iluminuras, já tratada anteriormente, a função didática. Se o papel da iluminura em bestiários era de transmitir de forma visual o conhecimento transmitido no texto, e a iluminura era uma síntese de passagens selecionadas, logo, a iluminura possui uma importância tão grande quanto o texto. Clark sugere que o papel do bestiário era provavelmente relacionado a 
uma educação básica de conhecimentos cristãos, seja de crianças ou de layman ${ }^{15}$, Ron Baxter acredita que alguns eram destinados à educação privada ${ }^{16}$, especialmente os de luxo, afirmação que Clark também compartilha. A maior parte das teorias já criadas para a função e utilização do bestiário, está relacionada à educação. Se, como disse Gregório, a imagem é como o texto para o iletrado ${ }^{17}$, podemos observar nos bestiários que a imagem, por si só, dificilmente consegue transmitir o conteúdo sem o auxílio do texto; por conseguinte pode-se supor que os textos eram lidos para os iletrados e as imagens serviam como um reconhecimento visual da abstração textual, ou o texto era lido pelo letrado enquanto as imagens proporcionavam uma dimensão narrativa mais profunda do próprio texto, possivelmente um instrumento mnemônico. Em ambos os casos, a iluminura tem um papel conflituoso, está necessariamente submetida ao texto, mas ao mesmo tempo, está em um mesmo patamar de importância. Sua limitação física e material aliada com a necessidade de representar uma passagem textual que se deseja dar um suporte visual ou um aprofundamento narrativo fazem com que a passagem iluminada seja hierarquicamente mais importante que as outras.

Pelo seu poder de síntese, ênfase, e aproximação com o iletrado, a iluminura será então uma forma de ressaltar aquilo considerado mais importante no texto. Logo, uma iluminura raramente irá representar algo que não é respaldado pelo texto ou não possui significado metafórico relevante, exceto quando tal representação é requisitada, ou seja, quando há valor exterior ao manuscrito. Considerações sobre importância de mensagens transmitidas pela iluminura podem mudar de acordo com função, época e destino do bestiário, e, portanto, deve-se compreender e estudar justamente as mudanças imagéticas (e textuais) presentes em diferentes bestiários, e seu subsequente significado.

Os estudos de bestiários foram por muito tempo feitos de forma esporádica pela historiografia, mas em 1928 M. R. James com seu estudo e classificação dos bestiários em famílias intitulado The Bestiary deu o passo inicial para o desenvolvimento do estudo destes manuscritos. Já em 1960 Florence McCulloch revisou as classificações de James em seu livro Medieval Latin and French Bestiaries e cunhou as famílias que utilizamos até o presente momento no estudo de bestiários. A família ao qual os Mss. 24 e 1511 fazem parte é chamada de Segunda Família de bestiários latinos.

Existe também um tipo de manuscrito que se assemelha bastante ao bestiário, o aviário, que foi criado por Hugo de Fouilloy no início do século XII. Este tipo de literatura tratava exclusivamente de aves, e também descende da tradição do Physiologus, possuindo um caráter mais profundo nas lições morais que os bestiários. Alguns bestiários absorveram partes do aviário e incluíram em seus fólios, substituindo ou complementando aves já presentes nos bestiários, como os bestiários Ms. 24 e Ms. 1511.

17 Atualmente, diversos estudos já foram conduzidos sobre estes manuscritos, mas o tópico ainda se mantém afastado da produção histórica tradicional sobre a Idade Média. Já foram, em alguns casos, analisados sob a ótica do patrocínio, especialmente por Ron Baxter e Xenia Muratova, que analisaram exemplares de luxo destes manuscritos. Muratova, em seu artigo Workshop Methods in English Late Twelfth Century Illumination and the Production of Luxury Bestiaries, se limitou em analisar a semelhança estilística das iluminuras presentes nos bestiários Bodley Ashmole Ms. 1511 e Aberdeen Bestiary Ms. 24, bestiários que são o foco deste estudo. A autora diz que tais semelhanças observadas fizeram-na crer que ambos foram feitos em um mesmo scriptorium por um mesmo 
mestre com a ajuda de aprendizes e, por esta razão, a autora os caracteriza como manuscrits frères ${ }^{18}$.

Bestiários de luxo não são manuscritos comuns, são decorados com uma gama de pigmentos, e comumente possuem folheamento de ouro. A produção de bestiários de luxo era delegada a escribas, iluminadores e possivelmente coloristas ${ }^{19}$, podendo contar inclusive com pigmentos onerosos como o azul ultramarino ${ }^{20}$, capas rebuscadas e pergaminhos finos de qualidade superior. Em contrapartida, bestiários que não são de luxo possuem menos pigmentos, traços menos seguros, pergaminhos de baixa qualidade e não são folheados a ouro. Bestiários originários de mosteiros que faziam parte da ordem de Cister eram, normalmente, ausentes de qualquer coloração ou decoração de ouro ${ }^{21}$ enquanto outras ordens as utilizavam quando podiam. Pedidos de manuscritos luxuosos eram normalmente feitos a mosteiros que já possuíam experiência na produção de manuscritos luxuosos; tais características apresentadas podem nos explicar o motivo de Muratova ter levantado a hipótese de que tanto o Ms. 1511 quanto o Ms. 24 possam ter sido produzidos em um scriptorium, ou workshop, dedicado e experiente na produção de manuscritos luxuosos ${ }^{22}$.

Caracterizados pelo uso de cores profundas e folheamento de ouro, ambos bestiários, Ms. 1511 e Ms. 24, são exemplos de bestiários fruto de uma produção de luxo da Inglaterra medieval. O primeiro é datado do fim do século XII ou início do XIII ${ }^{23}$, e o segundo possui a mesma datação, mas ainda não se sabe o local de produção de ambos. Muratova defende que o estilo de iniciais menores do Ms. 1511 pode estar ligado ao norte da Inglaterra, enquanto o estilo do Ms. 24 está mais próximo do estilo característico de Londres e Oxford ${ }^{24}$. Willene B. Clark contesta várias sugestões de Muratova, entre elas a existência de um iluminador em comum entre ambos os bestiários, apesar de concordar que são pintores bastante próximos ${ }^{25}$. Há no campo acadêmico uma discussão prolífica sobre a materialidade e localização de produção de ambos bestiários, discussão esta que é liderada principalmente pelas duas autoras supracitadas. Clark, acadêmica referência no estudo de bestiários e aviários ${ }^{26}$, concorda com Muratova quanto ao visual profissional dos Ms. 1511 e Ms. 24, corroborando com a teoria de que possivelmente foram produzidos em locais, ou local, especializados na produção de manuscritos de luxo.

Uma das várias iluminuras que se mostram quase idênticas são as do pássaro Pica, conhecido em português como Pêga ${ }^{27}$, onde foi iluminada uma cena onde há um caçador lançando uma flecha em uma das Pêgas que estão pousadas em uma árvore. Os pássaros representados são da subespécie da eurásia, de penas negras com partes brancas nas asas e peito. Esses pássaros são endêmicos do continente europeu, e fazem parte de contos folclóricos e superstições de partes da Europa ${ }^{28}$, indicando que havia uma relação de, ao menos, observação destes pelos humanos. De acordo com as informações recolhidas por Carol Neuman de Vegvar, as Pêgas sofreram mudanças em seu significado simbólico; fontes clássicas como Ovídio e Plínio, o Velho; tratam o pássaro como um animal bastante vocal e, em conjunto com autoridades como Isidoro de Sevilha e Hugo de Folieto, em um tom positivo ou neutro. Posteriormente, com Hildegarda de Bingen e Alexander Neckham, a Pêga é vista de forma negativa, visão esta que reverbera durante o fim do medievo e início da modernidade ao tratar a Pêga como um animal que traz má sorte e rouba coisas ${ }^{29}$. Este pássaro e sua iluminura, assim como a relação entre o ser humano e a natureza, possuem papel fundamental na análise 
dos bestiários Ms. 24 e Ms. 1511 e seu patrocínio por alguém da elite medieval inglesa, e corroboram com a hipótese de que foram produzidos em um mesmo local.

\section{Evidências Materiais e Visuais}

Como previamente apontado, a heráldica é uma das formas de identificação de patrocínio em bestiários pela elite social medieval, como é o caso do manuscrito Ms. Bodley 764. Analisado por Ronald Baxter em seu artigo A Baronial Bestiary: Heraldic Evidence for the Patronage of MS. Bodley 764, há neste bestiário a presença de escudos heráldicos que podem indicar o patrocínio de tal manuscrito: o indício está presente na iluminura do elefante, onde o animal porta três escudos passíveis de identificação. 0 Ms. 764 é também um dos poucos bestiários de luxo, onde observa-se cores profundas e folheamento de ouro. Seu estilo de iluminação e modelo de animais diferem daqueles observados no Ms. 1511 e Ms. 24, mas ainda possuem um grau de semelhança ${ }^{30}$, como foi observado por Clark. Os três bestiários fazem parte da segunda família de bestiários latinos, e foram produzidos na Inglaterra. No entanto, a semelhança entre os manuscritos não se explica ou limita em razão do pertencimento da mesma família, há entre eles uma similaridade que transcende a catalogação familiar e os aproxima de uma possível descendência de modelos imagéticos ${ }^{31}$, como notado por Clark.

Como dito anteriormente, a relação entre texto e imagem é uma questão fundamental na análise de bestiários, pois o vínculo entre texto e iluminura se expressa no momento em que a imagem reflete o conteúdo textual do manuscrito. Considerando que há um corpo textual, espera-se que a relação entre imagem e texto faça com que as iluminuras tendam a representar uma das passagens descritas no tratado animal. Logo, a imagem em bestiários é, normalmente, limitada pelo texto, mas é possível observar em algumas iluminuras que a iluminura apresenta elementos extra-textuais.

Observando o princípio da relação entre imagem e texto, podemos identificar nos bestiários Mss. 24 e 1511 que a iluminura da Pica extrapola a relação ao exibir elementos extra-textuais. Iniciando no manuscrito Aberdeen Bestiary Ms. 24, podemos observar na iluminura do fólio $37 \mathrm{r}$ a representação de uma grande árvore com seis galhos, onde quatro Pêgas nas cores preto e branco estão pousados de forma simétrica. Sob a árvore, há um homem de cabelo ruivo curto segurando um arco de qual acaba de lançar uma flecha direcionada a um dos pássaros. 0 homem veste uma túnica vermelha ricamente decorada com a cor branca; por baixo dessa, usa uma blusa larga azul que sobre seus braços até os punhos, sua calça é azul e usa botas laranjas. A árvore é azul e possui as folhas vermelhas, o fundo da iluminura é decorado com folheamento de ouro polido, são percetíveis alguns pontos de desgaste do folheamento, onde observa-se uma cor ocre avermelhada ${ }^{32}$. Seu pé direito atravessa a moldura que define a centralização da iluminura e chega até à parte superior de uma palavra, a moldura é levemente vermelha com decorações brancas com ziguezagues e pontos. É possível identificar furos que seguem as linhas definidoras da representação do caçador; esses furos são decorrentes de uma técnica de transferência de iluminura conhecida como pouncing ${ }^{33}$ onde, com um fino instrumento, vários furos são feitos ao redor da iluminura que se deseja copiar e então coloca-se algum tipo de pó, normalmente pó de carvão, que irá marcar o pergaminho logo abaixo do copiado. Com os pontos definidos pelo pó de carvão, traça-se o esboço da iluminura e assim se transfere o mesmo modelo de iluminura para um outro manuscrito. É interessante notar que somente há furos ao 
redor do caçador, e não do conjunto da iluminura, mostrando que apenas o modelo do caçador foi transferido para um outro manuscrito.

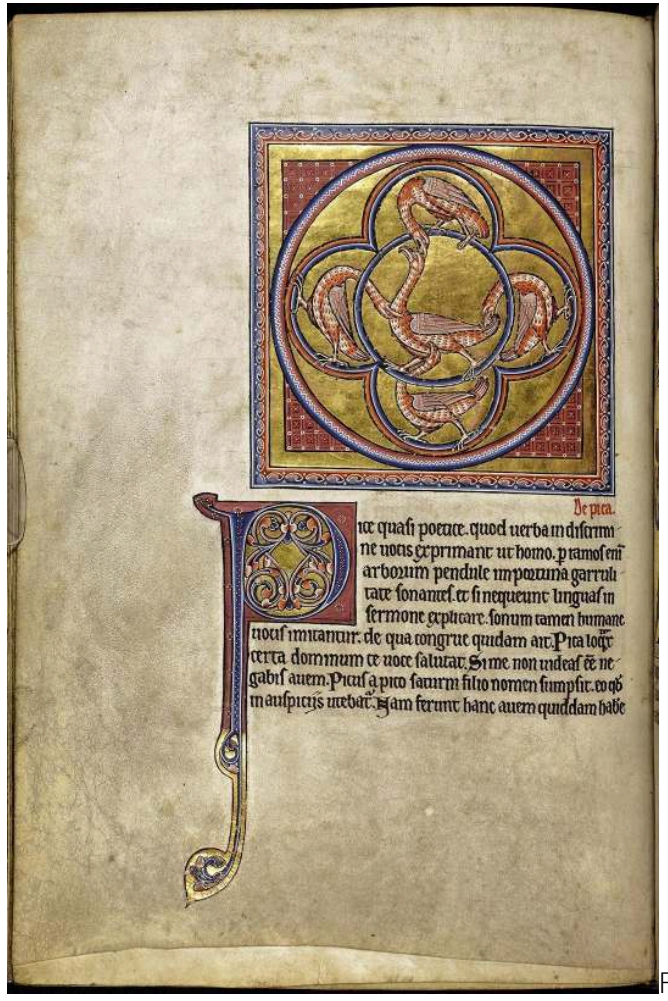

ig. 1 - Ms 24, fólio 36v³4.

(c) Biblioteca da Universidade de Aberdeen

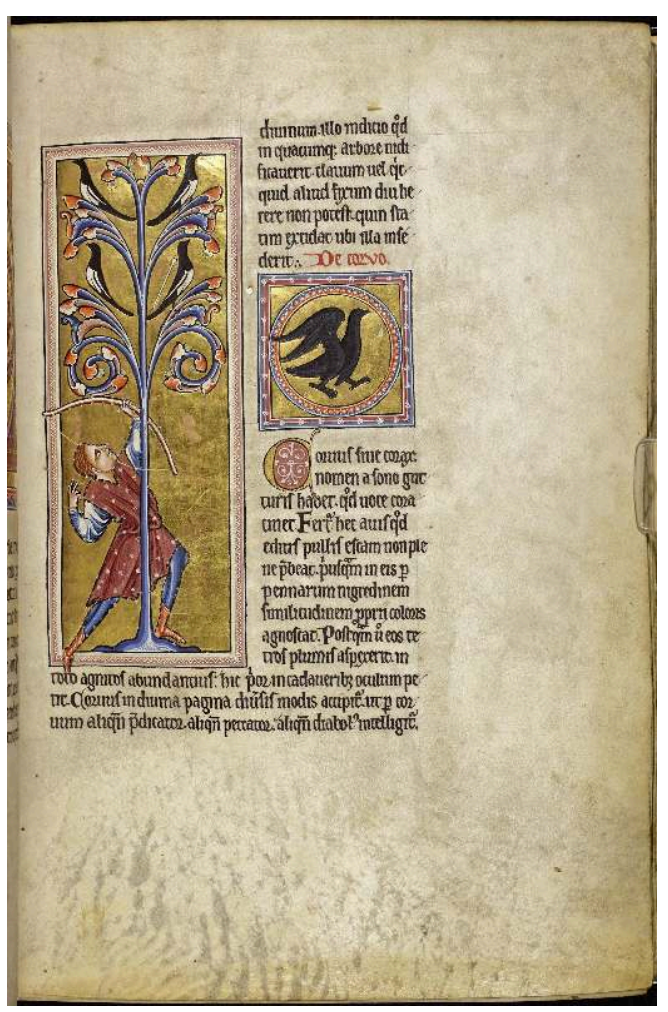

Fig. 2 - Ms. 24, fólio 37r.

(c) Biblioteca da Universidade de Aberdeen 


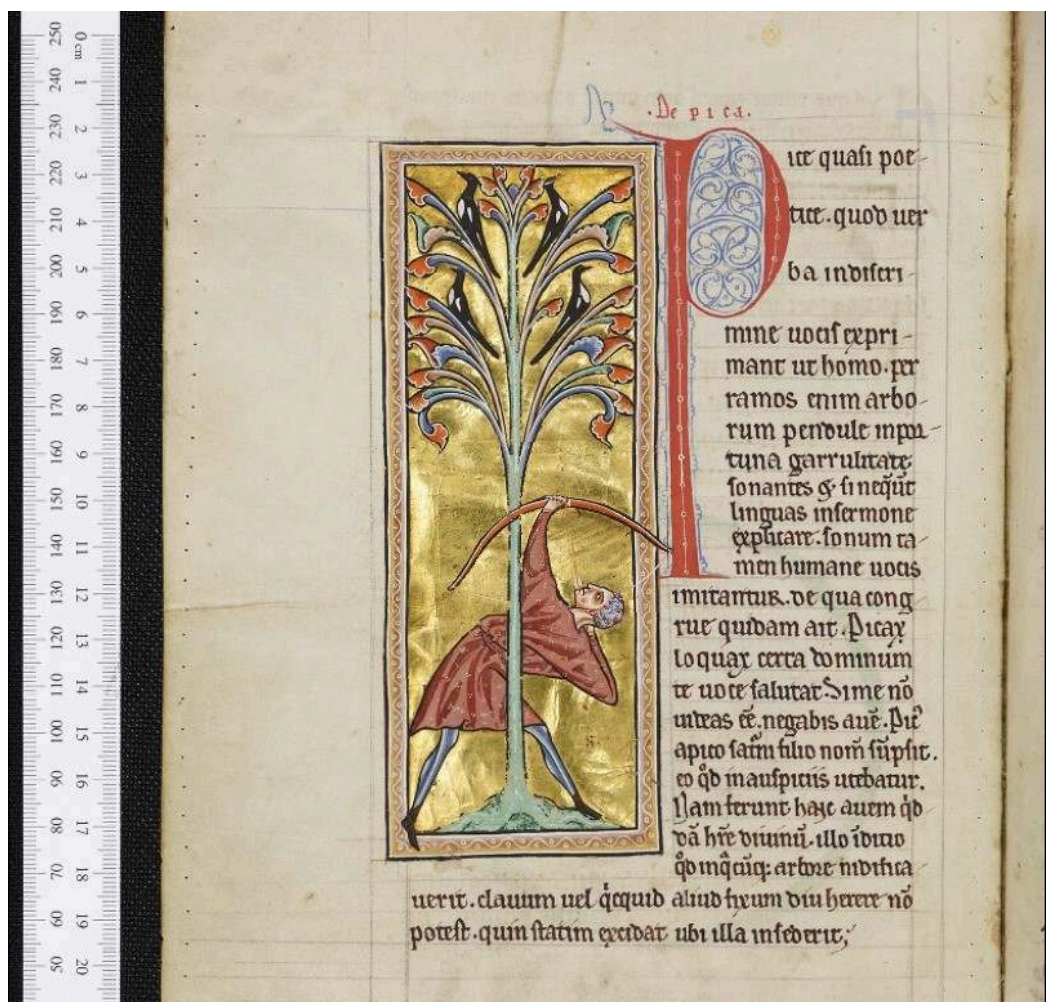

Fig. 3 - Ms. 1511, fólio 48v35.

(c) BODLEIAN LIBRARY

A Pêga do manuscrito Ms. 1511 é representada de forma bastante similar, as principais diferenças são: a posição do caçador, que é representado de forma que seus pés apontam para frente e seu torso para trás como em uma estranha pose de caça; a túnica do caçador possui mangas longas; seu cabelo não é ruivo; seu arco ainda está tensionado; e a flecha possui um formato triangular na ponta. Das principais semelhanças, cabe apontar que o mesmo pé do caçador está atravessando a moldura e a árvore e as Pêgas são de uma semelhança enorme.

A segunda iluminura, do Ms. 1511, possui 15.3 centímetros de altura, e é impossível, através do formato digital, determinar sua largura ou as dimensões da iluminura do bestiário de Aberdeen, mas claramente são muito grandes quando comparadas com o tamanho dos fólios, o que pode nos indicar que há nelas uma grande importância, uma vez que o tamanho da iluminura indica sua posição hierárquica.

Para apontarmos de forma empírica se há realmente uma relevância relativa ao tamanho da representação do pássaro Pêga nestes dois manuscritos, devemos verificar se esta representação encontrada em ambos os manuscritos reflete-se em outros, indicando assim se é um modelo que é seguido por bestiários em geral ou o modelo do Ms. 24 e Ms. 1511 é atípico. Quando comparadas às iluminuras de bestiários da segunda família e um da primeira, podemos perceber que os Ms. 24 e 1511 se diferenciam bastante em seu tamanho e representação. Nas iluminuras da Pêga presentes nos manuscritos BnF Ms. lat. $6838 b^{36}$, BnF Ms. lat. $3630^{37}$, Canterbury Ms. Lit. D $10^{38}$, Kongelige Ms. Gl. kgl. S. $16334^{439}$, Northumberland Bestiary Ms. $100^{40}$ e Morgan Ms. $81^{41}$ (este conta com folheamento de ouro, um manuscrito de luxo), podemos identificar que há uma similaridade muito grande entre os seis manuscritos, onde, em um pequeno espaço, as Pêgas são iluminadas sozinhas ou em dupla, destes apenas duas iluminuras 
representam uma Pêga sobre uma árvore ${ }^{42}$. Nestes manuscritos citados, os pássaros ocupam um pequeno espaço do fólio e são desenhados de forma bem simples, se diferenciando bastante das iluminuras dos Ms. 24 e 1511.

Considerando que em outros seis bestiários a Pêga ocupa uma proporção inferior do que no Ms. 24 e Ms. 1511, podemos retomar ao que Pastoureau nos disse sobre a hierarquia da iluminura de modo comparativo. É visível a diferença de tamanho entre as iluminuras, o que significa que nos Ms. 24 e Ms. 1511, a Pêga está em um grau hierárquico simbólico superior do que em outros manuscritos. Isso depende, é claro, de uma análise comparativa entre outras iluminuras de aves de cada bestiário, e ao fazê-la, percebemos que nos seis bestiários de controle, a iluminura da Pêga é do mesmo tamanho ou menor que outras, enquanto que, nos dois bestiários objetos deste estudo, as iluminuras se sobressaem das demais, ocupando um espaço dentro dos fólios que se compara apenas à Pomba, Hoopoe e Águia, sendo proporcionalmente maior do que as demais. É interessante lembrar que o Hoopoe possui um tratado bastante ligado à família, e a águia à elite. Portanto, podemos crer que o tamanho das iluminuras nos manuscritos MS. 24 e MS. 1511 é excepcionalmente maior que o das demais em um contexto comparativo com iluminuras de seu próprio manuscrito, e as comparando com outros manuscritos, reforçando a ideia de que especificamente estas iluminuras possuem uma graduação simbólica superior às outras.

As iluminuras dos dois bestiários de luxo nos Mss. 24 e 1511 possuem um outro elemento que as diferencia das demais, a presença de um caçador. A presença desta nova informação, que não se repete em outros manuscritos, poderia estar relacionada aos manuscritos de luxo, mas como podemos observar no Ms. 81, também de luxo, o caçador não aparece. Somos capazes de apontar que aparição do caçador é independente do luxo do manuscrito, e está intimamente relacionada ao grupo do Ms. 24 e Ms. 1511, o que pode reforçar a teoria de Muratova de que não só são manuscrits frères, mas possivelmente feitos em um mesmo workshop.

No entanto, a recorrência do motivo do caçador, presente apenas em um workshop, não explica sua existência e seu significado. A discrepância clara entre a grande utilização do espaço limitado nos fólios dos bestiários para a iluminura da Pêga em contraste com outras aves dos bestiários Ms. 1511 e Ms. 24, e em contraste também com outras iluminuras de outros seis bestiários, indica que a representação do caçador pode possuir um significado que se agrega ao da Pêga, extrapolando assim os vistos em outros bestiários.

31 Considerando a relação extremamente próxima entre texto e imagem, devemos nos voltar ao texto do tratado da Pêga para tentar identificar se nele há algo que explique a aparição do caçador, e o texto segue assim:

"Do Pêga, Pêgas são como poetas, porque eles pronunciam palavras, com um som distinto, como homens; pendurados em galhos de árvores eles tagarelam rudemente, e mesmo que não consigam colocar suas línguas em torno de palavras, eles mesmo assim imitam a linguagem humana. Sobre o assunto, algúem apropriadamente disse: 'O Pêga tagarela, firme na voz, te saúda como senhor. Se você não me ver, você negará que sou um pássaro.' (Marcial, Epigramas, 14:76). O pica-pau, picus, ganha seu nome de Picus, filho de Saturno, porque ele o usou para tomar augúrios. Pois eles dizem que esse pássaro tem algo divino sobre ele; a prova disso é, se um pica-pau se aninha em qualquer árvore, um prego ou qualquer coisa fixada no tronco não ficará lá por muito tempo, mas vai cair assim que o pássaro senta em seu ninho" ${ }^{43}$. 

Pica (Pêga) e o Picus (Pica-Pau), indicando que o tratado do segundo foi absorvido pelo primeiro. McCulloch confirma em sua classificação que a descrição do Picus foi unida à da Pica ${ }^{44}$, mas são animais diferentes. Reitero aqui que a mesma foi absorvida a partir da indicação da falta do incipit do Picus, incipit este que é comum no começo de tratados de bestiários. É necessário ressaltar que apesar de McCulloch apontar que essa absorção do tratado do Picus ocorre também em bestiários da primeira família e do tipo $H$ (Pseudo Livro de São Victor), podemos observar que a mesma também se repete no bestiário de Aberdeen, Ms. 1511, ambos da segunda família, e todos os outros aqui citados para análise comparativa.

Pouco é dito especificamente sobre a Pêga, que faz um barulho semelhante aos humanos, limitando-se a uma citação de um texto de Marco Valério Marcial, um romano. É impossível detetar no texto qualquer menção a um caçador, mas temos, no entanto, uma menção dentro da citação de Marcial sobre um lorde.

Recorrendo ao que já foi dito anteriormente sobre a relação entre texto e imagem, há uma necessidade de que a iluminura, por mais sintética e narrativamente independente que seja, tenha o texto como base, o que pode ou não ter ocorrido na iluminura da Pêga nos Ms. 24 e Ms. 1511. Se considerarmos que o homem representa um caçador, não possuímos referência textual a ele, mas se considerarmos que é um lorde, o texto embasa a imagem, representando a passagem do texto em que uma Pêga fala com o lorde, mas, diferentemente do texto, é vista pelo humano.

Devemos trabalhar com as duas possibilidades, que, ao meu ver, nos levarão a um caminho final semelhante. Considerando que é um caçador, devemos analisar os elementos que compõe este quebra-cabeças imagético, iniciando pela flecha. No Ms. 1511, vemos que a flecha é triangular padrão como conhecemos, mas o mesmo não ocorre no Ms. 24. É possível ver claramente que a flecha lançada pelo caçador no bestiário de Aberdeen não é uma flecha comum, mas uma flecha com a cabeça larga com uma ponta fina, bastante diferente de uma cabeça de flecha comum, com formato triangular. Este formato distinto acusa que o desenho da cabeça da flecha não foi um elemento negligenciado; pelo contrário, era intenção do iluminador representar um tipo específico de flecha, que possivelmente está intimamente associada à sua ação, a caça de pássaros. Oliver Jessop em seu artigo A New Artefact Typology for the Study of Medieval Arrowheads classifica as diferentes flechas utilizada durante o período medieval, utilizando uma catalogação cronológica e as dividindo em diversas categorias de acordo com sua utilização, forma, etc. Uma das flechas catalogadas é a H5, que corresponde exatamente à flecha representada na iluminura do Ms. 24, onde Jessop diz que apesar da falta de evidência arqueológica por causa de seu material, a catalogação da mesma foi possível a partir de sua representação em iluminuras medievais. $O$ autor sugere que ela poderia ter sido utilizada para caçar pássaros pequenos, e sua forma seria ideal pois atordoaria o pássaro, ou o mataria com o menor dano possível à sua carne ${ }^{45}$. A data cuja a cabeça de flecha H5 foi classificada fica entre os séculos XII e XIII.

Se a flecha é característica da caça de animais de pequeno porte e pássaros pequenos, devemos considerar que o homem na iluminura estava de fato caçando. No entanto, devemos refletir sobre a efetividade da caça. Ora, a Pêga é um pássaro pequeno, com pouquíssima carne, portanto, a caça do mesmo exige um esforço grande para um retorno nutricional pequeno, logo, sua caça sob uma perspectiva nutritiva, teoricamente, não faria sentido. Devemos então presumir que há um outro motivo por 
trás da caça da Pêga, e este talvez indique uma demonstração de poder e status através da caça.

Sabemos que durante o medievo a caça teve papel fundamental na vida dos humanos, mas teve uma função especialmente importante para as elites. A caça de grandes animais, como o veado, possuía um grande valor simbólico para a elite medieval, e por isso foram protegidos em reservas de caça. No entanto, pouco se fala sobre a caça de pequenos animais como os pássaros. Os pequenos pássaros eram caçados e consumidos pela elite como símbolos hierárquicos de poder e luxuosidade, e podemos dar tal sugestão a partir de alguns estudos zooarqueológicos. Dale Serjeantson indica em seu estudo zooarqueológico Dainty Dish que ossos de aves de pequeno porte foram recuperados nos dois sítios analisados, St. Gregory Priory (séculos XIV - XVI) e Little Pickle (século XVI), uma das aves encontrada foi a Pêga. Um dos métodos apresentados para a caça destes pequenos animais era algo que o autor chama de bird bolt, um tipo de seta destinado à caça destes animais, que imediatamente nos faz lembrar da flecha $\mathrm{H} 5$ representada na iluminura do Ms. 24. Por fim, o autor conclui que o consumo destes animais era limitado às refeições de alto nível e status social ${ }^{46}$. Na Hungria, obtemos resultados semelhantes de estudos zooarqueológicos, onde também foram encontrados vestígios de Pêgas próximos à residência real em Buda ${ }^{47}$ (datação estimada séculos XIII $\mathrm{e}$ XIV). Podemos presumir, então, que o consumo de pequenas aves selvagens está relacionado a um status social do consumo. Vegvar cita também a possibilidade das Pêgas terem feito parte da alimentação anglo-saxã ${ }^{48}$. Tal prestígio é resultado de um conjunto de diversos fatores, como disponibilidade de carne doméstica, exclusividade do pássaro pequeno e liberdade de caça.

A Pêga, assim como diversos outros pássaros de pequeno porte, poderia ser caçada com intuito de consumi-la pelo valor simbólico atrelado ao seu gênero de ave selvagem pequena. Logo, presume-se que o ato de caçar uma Pêga é, por definição, um ato simbólico das elites medievais.

Se considerarmos a segunda opção, de que aquele homem representado na iluminura é um lorde, e não só um caçador, podemos chegar à mesma conclusão, a representação imagética de um lorde caçador ou um caçador cumpre um mesmo papel: identificar e retratar um padrão da elite medieval que não observa-se em outro bestiário.

Portanto, podemos propor três pontos cruciais sobre as iluminuras do tratado da Pêga no Ms. 24 e Ms. 1511: há uma referência a um comportamento da elite; as iluminuras apresentam dimensões desproporcionais quando comparadas a outros bestiários e outras iluminuras do próprio bestiário (hierarquia); e não possuem uma clara relação entre imagem-texto. $O$ elemento do caçador foge da relação entre imagem e texto $\mathrm{e}$ estabelece uma conexão supra-textual que pode ser identificada pelo leitor ou leitora, e, assim como os outros dois pontos, pode ser explicada através do patrocínio do manuscrito.

41 A existência de um elemento, o caçador, que não existe em outros bestiários pode indicar que este componente está ali como uma referência ao seu patrono. Seria difícil apontar com exatidão qual o patrono dos manuscritos, mas podemos presumir que o mesmo faria parte de uma elite social medieval baseando-nos nos pontos já abordados. A hierarquia simbólica entre as iluminuras e a relação texto-imagem reforça a ideia de que o caçador é um elemento único da iluminura que, ao mesmo tempo que mostra ligações supra-textuais, se encontra também valorizado. Sua relação com uma ave que poderia ser consumida pelas elites, e de valor simbólico, indica que estes manuscritos, 
pelas características da iluminura da Pêga, possivelmente foram produzidos para um patrocinador que se preocupava com a exposição de detalhes específicos.

As semelhanças entre os Ms. 24 e Ms. 1511, no entanto, não excluem suas diferenças. Já foi sugerido que, por questões estilísticas, o bestiário de Aberdeen poderia ter sido criado antes do Ms. $1511^{49}$, ou que ambos sejam uma cópia de um modelo comum ${ }^{50}$. É possível que ambos tenham sido produzidos a partir de um modelo comum, mas acredita-se que o bestiário de Aberdeen é uma criação posterior ao Ms. 1511. Uma diferença importante entre ambos Mss. é que em algumas iluminuras do Ms. 24, a técnica de transferência por meio de furos, pouncing, é detectada. Esta é uma prova empírica de que o bestiário de Aberdeen foi utilizado como modelo base para outros bestiários, enquanto que a ausência desses furos no Ms. 1511 sugere que este manuscrito provavelmente não serviu como modelo. contribuía para a distribuição das riquezas adquiridas pelos monarcas entre a aristocracia $^{51}$. De fato, o presente é uma forma de comunicação entre grupos ou indivíduos ${ }^{52}$, seja ela positiva, com o intuito de criar ou reforçar laços, ou antagônica, com o intuito de ser violenta ${ }^{53}$. Comuns durante o medievo, os presentes cobriam uma área abrangente que poderia ir da hospitalidade e coisas imateriais, a objetos materiais de valores econômicos e simbólicos variados. Diferentemente da caridade, o presenteamento cria uma obrigatoriedade de retribuiçãa ${ }^{54}$, estabelecendo uma relação de débito entre o destinatário e remetente que pode ser construtiva para o estreitamento e construção de laços familiares e sócio-políticos, ou causar um endividamento e desbalanceamento na estrutura social no status hierárquico. atenção aos manuscritos, em especial aos bestiários. Sarah Kay diz sobre os bestiários que "it is likely that monastic, ecclesiastical, or aristocratic networks operating between, rather than within, these imperial powers were responsible for much of the traffic in which these relationships between texts were forged"55. Dines sugere que as relações entre diferentes famílias textuais de bestiários (B-I, Segunda Família, Terceira, Dicta Chrysostomi, Theobaldi, etc.) provavelmente são resultado de indivíduos que atuam entre diferentes círculos sociais, monástico, eclesiástico e aristocrático ${ }^{56} \mathrm{e}$ estabelecem uma demanda e consumo de bestiários, o que causa as várias transformações textuais e imagéticas ${ }^{57}$.

A relação entre diferentes indivíduos entre grupos sociais forma uma rede de conexões extensa que se conectam a partir de laços positivos ou antagônicos que invariavelmente utilizam o dom como denominador comum. $\mathrm{O}$ objeto presenteado, caso produzido com o intuito de ser um presente, era adquirido por meio da contratação ou patrocínio dos serviços de artesãos ou artistas, no caso específico de manuscritos estes eram copistas e iluminadores que normalmente, em especial antes do século XIII, eram membros do corpo eclesiástico.

O emprego de especialistas na produção de manuscritos incluia pessoas cuja especialidade ia de cópia de manuscritos previamente existentes até a criação de um texto novo. A maior patrona de livros durante o medievo foi, sem dúvida, a Igreja, mas as elites seculares também tiveram parte nesta produção, uma vez que o patrocínio de livros muitas vezes estava ligado às questões de identidade, seja ela familiar, individual, ou de grupo social ${ }^{58}$, ou de autoridade ${ }^{59}$. A manufatura de um livro nunca foi barata, 
exigia grande esforço das partes envolvidas e expertise artística e, portanto, mesmo os livros mais simples custariam um investimento financeiro razoável, limitando assim quem poderia pagar pelo manuscrito e consumi-lo, visto as baixas taxas de alfabetização.

Visto os dados previamente apresentados sobre o papel do presenteamento, patrocínio e características dos Ms. 24 e Ms. 1511, apresento os exemplos onde os bestiários se encontram como objetos trama de conexões socioculturais entre pessoas e grupos.

O primeiro exemplo o Ms. Morgan $81^{60}$ que no fólio $1 \mathrm{v}$ possui uma anotação que atesta ter sido um presente de Philippus Apostolorum, que de acordo com Baxter foi cônego de Lincoln, para Deus, Igreja de Santa Maria e Cuthbert de Radeford ${ }^{61}$. $O$ autor acredita que o luxuoso bestiário, em conjunto com outros manuscritos, foi entregue em 1187 como um presente comemorativo para uma data específica e para a edificação dos irmãos. Podemos presumir que, com a data provável de estabelecimento e construção da Igreja de Radeford sendo $1126^{62}$, uma vez que esta é a data que Henrique I confirma a doação (donum) da Igreja e terras ${ }^{63}$, o evento comemorativo provavelmente ainda deveria estar relacionado com a construção e finalização da igreja. Sobre o doador, Hugh Thomas em sua pesquisa sobre clérigos seculares identifica Philippus Apostolorum como parte deste corpo eclesiástico que se relacionava diretamente com o público secular ${ }^{64}$. Os manuscritos presenteados por Apostolorum para a Igreja de Radeford mostram que os manuscritos foram produzidos com o intuito de serem doados como presentes de altíssimo nível e luxuosidade, nos mostrando como o bestiário poderia ser utilizado por membros da Igreja, educação dos irmãos, e em cerimônias de dom, possuindo assim uma dupla função.

O segundo exemplo é o Ms. Gonville \& Caius Coll. 372/621 que, de acordo com Clark, possui uma inscrição do século XIV no fólio 140v que diz que Johannes de Milham, franciscano, comissionou e deu o livro à comunidade. Há outra inscrição datada do século XV que diz que o livro estava em posse de Johannes Zouch, também franciscano $0^{65}$.

51 Além dos exemplos dados, Clark cita mais quatro bestiários (BL Ms. Harley 3244, St. John's Coll. Ms. 61, Wormsley Lib. BM 3731, Bodleian Ms. Tanner 110) que possuem evidências sólidas de uso monástico, e oito que possuem inscrições tardias de uso monástico. Um dos bestiários com inscrições tardias é o BL Ms. Roy. 12.F.13, que foi produzido por volta de 1230 e tem uma inscrição que data do século XIV que indica a posse do manuscrito pelo Priorado de Rochester ${ }^{66}$.

Uma vez abordados os bestiários de uso monástico, temos a segunda categoria, uso secular, que é menos comum. O maior exemplo de bestiários produzidos para o consumo de patronos seculares se encontra em uma referência explícita no bestiário de Philippe de Thaon, que dedica-o à sua patrona Aliz. Mais que apenas um exemplar, Thaon é responsável pela a criação de uma das subdivisões do bestiário medieval na língua vernácula. Lê-se na anotação:

"Philippe de Thaun into the French language

has translated the Bestiary, a book of science,

for the honour of a jewel, who is a very handsome woman,

Aliz is she named, a queen she is crowned,

queen she is of England, may her soul never have trouble!" 67

53 Aliz, como conhecemos hoje, Adeliza de Louvain foi a segunda esposa de Henrique I entre 1121 e a morte do rei em 1135. Conhecida por ter sido patrona de obras literárias, 
foi a responsável por patrocinar Philippe de Thaon ${ }^{68}$. Não fica claro se o bestiário foi feito por Thaon para Adeliza, ou se foi feito por Thaon a pedido de Adeliza. Este tipo de bestiário vernáculo é um dos poucos que podemos afirmar que pertenceu a alguém da realeza em virtude da dedicatória que não se encontra em outros bestiários latinos. Claramente percebe-se que há uma grande diferença entre bestiários da segunda família e o bestiário de Thaon (prosa/verso, número de tratados, vernáculo, etc), mas há aqui uma confirmação de que bestiários poderiam ter sua produção patrocinada, assim como ser objeto de presenteamento e consumo por parte da elite secular.

Temos também o exemplo do Ms. Bodley 764 que, ao contrário do anterior, é sugerido por fortes evidências que foi patrocinado pela família Montalt (Mohaut, Mohun). Como dito anteriormente, Baxter sugere que as evidências apontam para o patrocínio baronial deste manuscrito baseado nas seguintes afirmativas: é um manuscrito de luxo com folheamento de ouro e várias miniaturas coloridas; apresenta, na iluminura do elefante, os escudos de algumas famílias baroniais; o texto de um dos animais é derivado de um manuscrito chamado de Topographia Hibernica de Giraldus Cambrensis, cujo autor tem ligação com um família baronial que antagonizava com o então rei Henrique II $^{69}$. Clark admite a possibilidade, mas ressalta que a afirmação de Baxter exige cautela pois há interpolações no Ms. Bodley 764 de Hrabanus Maurus que revelam um aprofundamento teológico do bestiário ${ }^{70}$. A oposição entre o aprofundamento teológico e as marcas heráldicas apontadas por Clark nos levam a refletir sobre as diferenças entre usuários e patrocinadores, e que nem sempre estas funções remetem necessariamente à um mesmo indivíduo ou comunidade.

Vê-se a partir da apresentação dos bestiários e de dados recolhidos por Clark e Baxter que, apesar de serem mais comuns os usos e patrocínios monásticos, os bestiários também podem ter sido objetos de patrocínio por parte da elite secular e utilizados em cerimônias de dom. Os exemplos dos Ms. Morgan 81 e Bestiário de Thaon nos mostram que houve a produção de bestiários para servirem de presentes, o que nos leva à proposta inicial feita neste artigo: evidências sugerem que os bestiários Ms. 24 e Ms. 1511 foram produzidos por um patrono de alto nível hierárquico e financeiro com a intenção de que ao menos um fosse entregue como presente.

Em adição aos exemplos de bestiários, soma-se a análise dos dois bestiários feita aqui, que nos permite levantar a hipótese de que ambos os manuscritos apresentam evidências de patrocínio pela elite medieval, baseando-nos no estudo das evidências materiais contidas nos manuscritos, assim como as evidências visuais e imagéticas representadas na iluminura da Pêga. Estes bestiários, no entanto, tiveram destinos diferentes, onde um serviu de modelo em ao menos um scriptorium e o outro não. Sabemos também que foram produzidos em uma diferença de tempo bastante curta ${ }^{71}, \mathrm{e}$ que bestiários de luxo não eram manuscritos comuns, considerando o pequeno número de bestiários luxuosos remanescentes. Proponho então que ambos manuscritos foram patrocinados por uma mesma pessoa, mas com destinos diferentes. O Ms. 24, em algum momento, não sabemos se logo após sua criação ou posteriormente, fez parte de um scriptorium que produzia bestiários, enquanto o Ms. 1511 talvez não tenha feito parte de um scriptorium, mas pode ter tido, e provavelmente o teve, uma função pedagógica da moral cristã na educação da elite medieval. Sua similaridade e correspondência na iluminura da Pêga indica que ambos os manuscritos podem ter sido produzidos para um mesmo patrono, e se não o foram, indicam um padrão de iluminura característico de um workshop que produz manuscritos de luxo para a elite medieval. 

fatores: o luxo dos manuscritos restringe o número de pessoas capazes de investir uma grande quantia em manuscritos; a similaridade entre os Mss. 24 e 1511 aponta que foram feitos em um mesmo scriptorium com capacidade de produzir manuscritos de luxo, restringindo os possíveis locais de produção; as datações que, quando muito, diferenciam-se em apenas 10 anos também indicam que foram feitos para um mesmo patrono. Baxter estipula que a média de bestiários em bibliotecas monásticas era próximo de 3 a cada 1000 volumes $^{72}$, ou seja, não eram tão populares quanto a historiografia tradicional propôs. Os cálculos de Baxter implicam para este estudo que, apesar de estarem situados no auge da produção de bestiários, a produção de dois manuscritos virtualmente iguais e luxuosos como os Mss. 24 e 1511 em um período estimado tão curto indicam que há apenas um responsável pelo patrocínio de ambos manuscritos.

Baseando-nos em evidências materiais e visuais, sugere-se então que o responsável pelo patrocínio de ambos manuscritos é um indivíduo que faz parte da elite. Não apenas pelo luxo investido nos manuscritos, mas pelas características extra-textuais apresentadas na iluminura da Pêga, que podem representar visualmente práticas vinculadas à elite. A aparente produção gêmea dos manuscritos em tão curto espaço de tempo e sua semelhança nos levam a crer que ao menos um dos bestiários foi produzido com o intuito de ser um objeto comemorativo para ser presenteado a alguém ou a alguma instituição, como era costumeiro nas interações sociais entre indivíduos, grupos e instituições durante o medievo. Se aceitarmos esta hipótese, devemos voltar nossa atenção em buscar os possíveis contextos motivadores para a produção destes dois luxuosos manuscritos, como comemorações, festividades ou inaugurações, que possam ter sido o palco da doação destes manuscritos.

\section{BIBLIOGRAFIA}

Fontes Manuscritas

Aberdeen, Aberdeen University Library, Ms. 24. Disponível em http://www.abdn.ac.uk/bestiary/.

Canterbury, Canterbury Cathedral Library, Ms. Lit. D 10. Disponível em: https://ims.canterburycathedral.org/advsearch.tlx?advsearchid=1537809368>.

Copenhague, Kongelige Bibliotek, Ms. Gl, kgl, S. 1633 4․․ Disponível em http://www.kb.dk/ permalink/2006/manus/221/eng/50+recto/?var=.

Los Angeles, Getty Museum, Northumberland Bestiary Ms. 100. Disponível em http:// www.getty.edu/art/collection/objects/240115/unknown-maker-northumberland-bestiaryenglish-about-1250-1260/?dz=0.5000,0.5000,0.67.

Nova Iorque, Morgan Library Ms. 81. Disponível em http://ica.themorgan.org/manuscript/ thumbs/77019. 
Oxford, Bodleian Library, Ms. Ashmole 1511. Disponível em https://digital.bodleian.ox.ac.uk/ inquire/p/fb43631c-1f61-4865-806c-9fe59b5753ff.

Paris, BnF, Ms. lat. 6838b. Disponível em http://mandragore.bnf.fr/ark:/12148/cgfbt65935s.

Paris, BnF, Ms. lat. 3630. Disponível em https://gallica.bnf.fr/ark:/12148/btv1b100329427/

f90.image. $r=3630 \% 20$ bestiaire.

Estudos

BAXTER, Ron - Bestiaries and Their Users in the Middle Ages. Phoenix Mill: Sutton, 1998.

BAXTER, Ronald - "A baronial bestiary: heraldic evidence for the patronage of MS. Bodley 764". Journal of the Warburg and Courtauld Institutes 50 (1987), pp. 196-200.

BENTON, Janetta Rebold - Materials, Methods, and Masterpieces of Medieval Art. Santa Barbara: ABCCLIO, 2009.

CLARK, Willene B. - A Medieval Book of Beasts: The Second-Family Bestiary: Commentary, Art, Text and Translation. Woodbridge: Boydell Press, 2006.

CLARKE, Mark - “Anglo-Saxon manuscript pigments”. Studies in Conservation 49/4 (2004), pp. 231-244.

COWELL, Andrew - The Medieval Warrior Aristocracy: Gifts, Violence, Performance, and the Sacred. New York: Boydell \& Brewer, 2007.

DAVIS, Henry William Carless; JOHNSON, Charles - Regesta regum anglo-normannorum, 1066-1154. Oxford: Clarendon Press, 1913.

DAVY, Marie-Madalene - Initiation à la Symbolique Romane. Paris: Flammarion, 1977.

DUBY, Georges - The early growth of the European economy: Warriors and peasants from the seventh to the twelfth century. New York: Cornell University Press, 1978.

DUBY, Georges - História Artística da Europa: A Idade Média, São Paulo: Editora Paz e Terra, 1997.

FOUILLOY, Hugh of; CLARK, Willene B. - The medieval book of birds: Hugh of Fouilloy's Aviarium. Edition, translation and commentary by Willene B. Clark. Binghamton (N.Y.): Medieval and Renaissance texts and studies, 1992.

GÁL, Erika - «"Fine Feathers Make Fine Birds": The Exploitation Of Wild Birds In Medieval Hungary». ANTÆUS 33 (2015), pp. 345-369, 2015.

GEDDES, Jane - "Observations on the Aberdeen Bestiary". Reinardus. Yearbook of the International Reynard Society 11 (1998), pp. 67-84.

JAMES, Montague R. - The Bestiary. Oxford: Roxburghe Club, 1928.

JESSOP, Oliver - "A new artefact typology for the study of medieval arrowheads". Medieval Archaeology 40/1 (1996), pp. 192-205.

JOHNS, Susan M. - Noblewomen, aristocracy and power in the twelfth-century Anglo-Norman realm. Manchester; New York: Manchester University Press, 2003.

KAY, Sarah - «'The English bestiary', the continental' Physiologus', and the intersections between them». Medium Aevum 85/1 (2016), pp. 118-142.

KUMLER, Aden - "The Patron-Function". in HOURIHANE, Colum (ed.) - Patronage: Power and Agency in Medieval Art. University Park: Penn State University Press, 2013, pp. 297-319. 
MCCULLOCH, Florence - Mediaeval Latin and French Bestiaries. Chapel Hill: University of North Carolina Press, 1962.

MCGRADY, Deborah - The Writer's Gift or the Patron's Pleasure? The Literary Economy in Late Medieval France. Buffalo: University of Toronto Press, 2019.

MERMIER, Guy R. - "The Phoenix: Its Nature and Its Place in the Tradition of the Physiologus". in CLARK, Willene B.; McMUNN, Meradith T. (eds.) - Beasts and Birds of the Middle Ages: The Bestiary and Its Legacy. Philadelphia: University of Pennsylvania Press, 1989, pp. 69-85.

MURATOVA, Xenia - "Workshop Methods in English Late Twelfth-Century Illumination and the Production of Luxury Bestiaries". in CLARK, Willene B.; McMUNN, Meradith T. (eds.) - Beasts and Birds of the Middle Ages: The Bestiary and Its Legacy. Philadelphia: University of Pennsylvania Press, 1989, pp. 53-68.

PASTOUREAU, Michel - Bestiaires du Moyen Âge. Paris: Seuil, 2011.

SCHMITT, Jean-Claude - O Corpo das Imagens: Ensaio Sobre a Cultura Visual na Idade Média. Bauru: EDUSC, 2007.

SERJEANTSON, Dale - "A dainty dish: consumption of small birds in Late Medieval England". in BUITENHUIS, H. and PRUMMEL, W. (eds.) - Animals and Man in the Past. Essays in Honour of Dr. A.T. Clason, Emeritus Professor of Archaeozoology Rijksuniversiteit Groningen, the Netherlands. (ARC-Publicaties: Archaeological Research and Consultancy Publication, 41) Groningen, Holland: ARC-Publicaties, 2001, pp. 263-274.

STACYE, J. - "Priory and Parish Church of Worksop or Radford, Nottinghamshire". Journal of the British Archaeological Association: First Series 30/2 (1874), pp. 156-170.

SWAINSON, Charles - Provincial Names and Folk Lore of British birds. Londres: English Dialect Society, Trübner and Co., 1885.

TEODORESCU, Bianca M.; CALIN, Răzvan-Alexandru; BUSU, Oprea-Valentin. - "Communication Gift Code". New Approaches in Social and Humanistic Sciences 1/1(2016), pp. 503-506.

THOMAS, Hugh M. - The Secular Clergy in England, 1066-1216. Oxford: Oxford University Press, 2014.

VEGVAR, Carol Neuman de - "Birds of a Feather: Magpies in the Bayeux Tapestry?". in FREDERICK, Jill; HYER, Maren Clegg (eds.) - Textiles, Text, Intertext: Essays in Honour of Gale R. Suffolk: Owen-Crocker. Boydell and Brewer, 2016, pp. 85-102.

\section{NOTAS}

1. Especialmente durante e após o renascimento do século XII.

2. DUBY, Georges - História Artística da Europa: A Idade Média. São Paulo: Editora Paz e Terra, 1997, p. 54.

3. A contagem de manuscritos participantes da Segunda Família de bestiários e a seleção de manuscritos de luxo foi feita por Willene B. Clark em: CLARK, Willene B. - A Medieval Book of Beasts: The Second-Family Bestiary: Commentary, Art, Text and Translation. Woodbridge: Boydell Press, 2006, p. 85.

4. BAXTER, Ronald - "A baronial bestiary: heraldic evidence for the patronage of MS. Bodley 764". Journal of the Warburg and Courtauld Institutes 50 (1987), pp. 196-200. 
5. MERMIER, Guy R. - "The Phoenix: Its Nature and Its Place in the Tradition of the Physiologus". in CLARK, Willene B.; McMUNN, Meradith T. (eds.). - Beasts and Birds of the Middle Ages: The Bestiary and Its Legacy. Philadelphia: University of Pennsylvania Press, 1989, p. 69.

6. "S'ils s'attardent sur les «propriétés " des bêtes et sur les merveilles de leurs «natures», ce n'est pas tant pour disserter sur la anatomie, l'éthologie ou la biologie des animaux que pour célébrer la Création et le Créateur, pour enseigner les vérités de la foi, pour inviter les fidèles à se convertir". (Tradução própria) PASTOUREAU, Michel Bestiaires du Moyen Âge. Paris: Seuil, 2011, p. 11.

7. "L'univers étant le symbole des réalités spirituelles". (Tradução própria) DAVY, Marie-Madalene - Initiation à la Symbolique Romane. Paris: Flammarion, 1977, p. 36.

8. CLARK, Willene B. - A Medieval Book of Beasts ..., p. 45.

9. PASTOUREAU, Michel - Bestiaires du Moyen Âge..., p. 39.

10. DUBY, Georges - História Artística da Europa..., p. 65.

11. SCHMITT, Jean-Claude - O Corpo das Imagens: Ensaio Sobre a Cultura Visual na Idade Média. Bauru: EDUSC, 2007, p. 97.

12. O texto do abutre inicia no fólio $44 \mathrm{r}$ e termina no fólio $45 \mathrm{r}$, sua iluminura está presente no fólio $44 \mathrm{v}$.

13. “(...) les enlumineurs sont conduits à faire des choix, à laisser de côté certains passages du texte, à en condenser d'autres; puis, avec ce qu'ils ont retenu, soit à compartimenter la page (cas le plus fréquent), soit à fusionner en une seule scène les différent caractères, attributs, comportements, récits et croyances concernant cet animal. Ce faisant, ils fabriquent une sorte d'image de synthèse, fidèle à l'esprit du texte mais qui n'est pas l'illustration pure et simple de sa lettre." PASTOUREAU, Michel - Bestiaires du Moyen Âge..., p. 42.

14. Não que a mesma não existisse, mas pressupõe uma questão de individualidade e liberdade artística, discussão esta que é recorrente e palco de diversos debates na História da Arte e História Medieval.

15. CLARK, Willene B - A Medieval Book of Beasts ..., p. 98.

16. BAXTER, Ron - Bestiaries and Their Users in the Middle Ages. Phoenix Mill: Sutton, 1998, p. 209.

17. SCHMITT, Jean-Claude - 0 Corpo das Imagens ..., p. 96.

18. MURATOVA, Xenia - "Workshop Methods in English Late Twelfth-Century Illumination and the Production of Luxury Bestiaries". in CLARK, Willene B.; McMUNN, Meradith T. (eds.) - Beasts and Birds of the Middle Ages: The Bestiary and Its Legacy. Philadelphia: University of Pennsylvania Press, 1989, p. 53.

19. BENTON, Janetta Rebold - Materials, Methods, and Masterpieces of Medieval Art. Santa Barbara: ABC-CLIO, 2009, p. 6.

20. CLARKE, Mark - "Anglo-Saxon manuscript pigments". Studies in Conservation 49/4 (2004), p. 235.

21. GEDDES, Jane - "Observations on the Aberdeen Bestiary". Reinardus. Yearbook of the International Reynard Society 11 (1998), p.74.

22. MURATOVA, Xenia - "Workshop Methods in English Late Twelfth-Century Illumination and the Production of Luxury Bestiaries"..., p. 54. 
23. M. R. James data os manuscritos como sendo do final do século XII, no entanto Willene B. Clark os data de 1200-10, já no início do século XIII. Neste artigo, segue-se a classificação de Clark.

24. MURATOVA, Xenia - "Workshop Methods in English Late Twelfth-Century Illumination and the Production of Luxury Bestiaries"..., p. 54.

25. CLARK, Willene B - A Medieval Book of Beasts ..., p. 73.

26. $O$ aviário é muito similar ao bestiário, no entanto, restringe-se à representação de uma miríade de aves. Os aviários tiveram início com Hugo de Fouilloy, já no século XII.

27. Se reconhece melhor o pássaro pelo seu nome em inglês, Magpie, mas a espécie tratada aqui é o pêga-europeu, nome científico Pica-pica.

28. SWAINSON, Charles - Provincial Names and Folk Lore of British birds. Londres: English Dialect Society, Trübner and Co. 1885, p. 218.

29. VEGVAR, Carol Neuman de - "Birds of a Feather: Magpies in the Bayeux Tapestry?". in FREDERICK, Jill; HYER, Maren Clegg (eds.) - Textiles, Text, Intertext: Essays in Honour of Gale R. Suffolk: Owen-Crocker. Boydell and Brewer, 2016, p. 92.

30. A ordem e textos dos aviários entre os três bestiários coincidem e foram organizados por Clark no mesmo grupo.

31. CLARK, Willene B - A Medieval Book of Beasts ..., p. 224.

32. Esta cor ocre é resultado de uma técnica de aplicação da folha de ouro.

33. BENTON, Janetta Rebold - Materials, Methods, and Masterpieces of Medieval Art ..., p. 48.

34. Agradeço enormemente a Biblioteca da Universidade de Aberdeen por disponibilizar as iluminuras em formato digital.

35. Agradeço também a Bodleian Library por disponibilizar as iluminuras em formato digital.

36. Segunda Família.

37. Segunda Família

38. Segunda Família

39. Segunda Família

40. Segunda Família

41. Segunda Família

42. BnF Ms. lat. 6838b e Canterbury Ms. Lit. D 10.

43. $O$ texto foi traduzido do inglês, disponibilizado pela biblioteca de Aberdeen, com eventuais consultas ao texto em latim. Texto em inglês: "Of the magpie Magpies are like poets, because they utter words, with a distinct sound, like men; hanging in the branches of trees, they chatter rudely, and even if they cannot get their tongues round words, they nevertheless imitate human speech. On this subject someone aptly said: 'The chattering magpie, firm of voice, greets you as lord. If you do not see me, you will deny that I am a bird' (Martial, Epigrams, 14: 76). The woodpecker, picus, gets its name from Picus son of Saturn, because he used it for taking auguries. For they say that this bird has something divine about it; the proof of this is, if a woodpecker nests in any tree, a nail or anything fixed in the trunk will not stay there for long, but will fall out as soon as the bird sits in its nest". Bestiário de Aberdeen MS. 24, Fólios 36v e 37r.

44. MCCULLOCH, Florence - Mediaeval Latin and French Bestiaries. Chapel Hill: University of North Carolina Press, 1962, p. 190. 
45. JESSOP, Oliver - "A new artefact typology for the study of medieval arrowheads". Medieval Archaeology 40/1 (1996), p. 199.

46. SERJEANTSON, Dale - "A dainty dish: consumption of small birds in Late Medieval England". in, Buitenhuis, H. and Prummel, W. (eds.) - Animals and Man in the Past. Essays in Honour of Dr. A.T. Clason, Emeritus Professor of Archaeozoology Rijksuniversiteit Groningen, the Netherlands. (ARC-Publications: Archaeological Research and Consultancy Publication, 41) Groningen, Holland: ARC-Publicaties, 2001, p. 273.

47. GÁL, Erika - «"Fine Feathers Make Fine Birds": The Exploitation Of Wild Birds In Medieval Hungary». ANTÆUS 33 (2015), p. 364.

48. VEGVAR, Carol Neuman de - "Birds of a Feather: Magpies in the Bayeux Tapestry ?"..., p. 90.

49. FOUILLOY, Hugh of; CLARK, Willene B. - The medieval book of birds: Hugh of Fouilloy's Aviarium. Edition, translation and commentary by Willene B. Clark. Binghamton (N.Y.): Medieval and Renaissance texts and studies, 1992, p. 78.

50. MURATOVA, Xenia - "Workshop Methods in English Late Twelfth-Century Illumination and the Production of Luxury Bestiaries"..., p. 54.

51. DUBY, Georges - The early growth of the European economy: Warriors and peasants from the seventh to the twelfth century. New York: Cornell University Press, 1978, p. 52.

52. TEODORESCU, Bianca M.; Calin, Răzvan-Alexandru; BUSU, Oprea-Valentin. "Communication Gift Code". New Approaches in Social and Humanistic Sciences 1/1(2016), pp. 503.

53. Ver COWELL, Andrew - The Medieval Warrior Aristocracy: Gifts, Violence, Performance, and the Sacred. New York: Boydell \& Brewer, 2007.

54. Ver a tese de MAUSS, Marcel - Essai sur le don: Forme et raison de l'échange dans les sociétés archaïques. Paris: Presses Universitaires de France, 2012.

55. KAY, Sarah - "'The English bestiary', the continental' Physiologus', and the intersections between them». Medium Aevum 85/1 (2016), pp. 118-142, p. 119.

56. Exclui-se aqui os camponeses pois não poderiam ser consumidores diretos de obras literárias religiosas como o bestiário visto o baixo número de alfabetizados e alto custo de produção de um manuscrito.

57. Apesar de Dines apenas tratar do texto, Baxter estabelece uma teoria similar para a compreensão das transformações e diferenças imagéticas entre bestiários.

58. Ver MONTERO, Elena Paulino - "Patrocinio religioso, patrocinio artistico e identidad familiar a finales de la Edad Media. El caso de los Fernandez de Velasco". eHumanista: Journal of Iberian Studies [em linha] 24 (2013), pp. 411-432. Consultado a 13 Outubro 2019. Disponível em https://www.ehumanista.ucsb.edu/sites/ secure.lsit.ucsb.edu.span.d7_eh/files/sitefiles/ehumanista/

volume24/09.ehuman.rectores.Paulino.pdf.; e, FELLOWS, Laura - Patronage as Power, Identity, and Self-Legitimization in Medieval Europe. Frederick Maryland: Hood College, 2018. Master Dissertation.

59. Ver MCGRADY, Deborah - The Writer's Gift or the Patron's Pleasure? The Literary Economy in Late Medieval France. Buffalo: University of Toronto Press, 2019.

60. Disponível em https://www.themorgan.org/collection/worksop-bestiary/6.

61. BAXTER, Ron - Bestiaries and Their Users in the Middle Ages ..., p. 195. 
62. DAVIS, Henry William Carless; JOHNSON, Charles - Regesta regum anglonormannorum, 1066-1154. Oxford: Clarendon Press, 1913, p. 201.

63. J. Stacye sugere que a data de fundação pode variar entre os anos 1123-1139. Ver STACYE, J. - "Priory and Parish Church of Worksop or Radford, Nottinghamshire". Journal of the British Archaeological Association: First Series 30/2 (1874), p. 160.

64. THOMAS, Hugh M. - The Secular Clergy in England, 1066-1216. Oxford: Oxford University Press, 2014, p. 259.

65. CLARK, Willene B - A Medieval Book of Beasts ..., p. 86.

66. CLARK, Willene B - A Medieval Book of Beasts ..., p. 86.

67. DE THAON, Philippe; WRIGHT, Thomas (ed.) - “The bestiary of Philippe de Thaon". in Popular Treatises on Science Written During the Middle Ages: in Anglo-Saxon, Anglo-Norman, and English. London: R. and J. E. Taylor 1891, p. 49.

68. JOHNS, Susan M. - Noblewomen, aristocracy and power in the twelfth-century AngloNorman realm. Manchester; New York: Manchester University Press, 2003.

69. BAXTER, Ron - Bestiaries and Their Users in the Middle Ages ..., p. 200.

70. CLARK, Willene B - A Medieval Book of Beasts ..., p. 87.

71. MURATOVA, Xenia - "Workshop Methods in English Late Twelfth-Century Illumination and the Production of Luxury Bestiaries"..., p. 55; FOUILLOY, Hugh of; CLARK, Willene B. - The medieval book of birds ..., p. 78.

72. BAXTER, Ron - Bestiaries and Their Users in the Middle Ages ..., p. 181.

\section{RESUMOS}

O presente artigo faz parte de uma pesquisa de mestrado em andamento na Universidade de Brasília (UnB), e propõe-se a indicar evidências visuais de patrocínio em dois bestiários medievais ingleses da segunda família, Bodley Ashmole Ms. 1511 e Aberdeen Bestiary Ms. 24. A proposta de patrocínio se apoia na teoria de que ambos são bestiários de luxo e de que possivelmente foram feitos por ao menos um iluminador em comum, e são resultado da cópia de um manuscrito base desconhecido. Procura-se afirmar esta teoria a partir de uma análise material e imagética dos manuscritos, onde dá-se foco na iluminura do pássaro Pica, chamado em português de Pêga. Tendo como base as teorias da relação entre texto-imagem e hierarquia de imagens, abordadas por diversos autores, o estudo feito aqui traça um paralelo comparativo entre os dois bestiários supracitados com outros seis manuscritos e identifica que há uma diferença além da estilística nas iluminuras. Considera-se que esta discrepância imagética pode estar relacionada ao patrocínio dos manuscritos, ou do manuscrito cujo modelo os serviu como base, nos fornecendo assim um olhar diferente e aprofundado sobre a produção de manuscritos de luxo e bestiários de luxo, e sua relação com a sociedade, como o consumo literário.

The present article is part of an ongoing Master's degree research in Universidade de Brasília (UnB), and proposes to indicate visual evidence of patronage in two British medieval bestiaries of the second family, Bodley Ashmole Ms. 1511 and Aberdeen Bestiary Ms. 24. The proposal of patronage is based on the theory that both are luxury bestiaries and which were possibly made 
by at least one illuminator in common, and are also the copies of an unknown manuscript. It is tried to affirm this theory from material and visual analysis of the manuscripts, where it is focused on the illumination of the bird Pica, called Pêga in Portuguese. Based on the theories of the relationship between text-image and hierarchy of images, addressed by several authors, the study here draws a comparative parallel between the two bestiaries mentioned above with six other manuscripts and identifies that there is a difference besides the stylistic in the illuminations. It is considered that this imaginary discrepancy may be related to the patronage of the manuscripts, or the manuscript which model served as the basis, thus providing us with a different and in-depth look at the production of luxury manuscripts and luxury bestiaries, and their relationship with society, such as literary consumption.

\section{ÍNDICE}

Keywords: Patronage, Aberdeen Bestiary, Ashmole Ms. 1511

Palavras-chave: Patronagem, Bestiário de Aberdeen, Ashmole Ms. 1511

\section{AUTOR}

\section{TIAGO DE OLIVEIRA VELOSO SILVA}

Universidade de Brasília, PPGHIS, Programa de Estudos Medievais (PEM), Bolsista CAPES.

71900100, Brasília, Brasil. tiagovs.his@gmail.com. tiago.veloso@aluno.unb.br. https://orcid.org/ 0000-0003-0371-9697 